Т. М. Клименко, Т. В. Сандуляк, О. А. Сердцева Харківська медична академія післядипломної освіти

\title{
ЦИФРОВА НЕРІВНІСТЬ ВИКЛАДАЧІВ І СЛУХАЧІВ У ПІСЛЯДИПЛОМНІЙ ОСВІТІ
}

\author{
T. M. Klimenko, T. V. Sandulyak, O. A. Serdtseva \\ Kharkiv Medical Academy of Post-Graduate Education \\ DIGITAL DIVIDE BETWEEN FACULTY AND STUDENTS \\ IN POST-GRADUATE EDUCATION
}

\begin{abstract}
Мета роботи - встановити причини недостатньої цифрової компетентності викладача та цифрової нерівності викладачів, слухачів і користувачів m-Health i e-Неalth послуг як проблеми переходу ВНЗ на дистанційну освіту та ширшого впровадження в електронну освіту і медицину сучасних цифрових технологій.

Основна частина. Розглядається суть і зміст нових компетенцій викладачів і слухачів із цифрових технологій у Рамці цифрової компетентності 2018 року та пов'язаних з нею інструментів, схвалених Європейським парламентом та Радою ЄС 17 січня 2018 року в оновленій редакції ключових компетентностей для навчання спеціалістів упродовж життя. Проаналізовано причини цифрової нерівності викладачів і слухачів курсів післядипломної освіти та користувачів систем електронної освіти та медицини, зроблено висновки щодо подолання цифрової нерівності викладачів, слухачів і користувачів цифрових технологій.

Висновки. Побудова ефективної електронної освіти та електронної охорони здоров'я неможлива без подолання цифрової нерівності слухачів і викладачів, лікарів і пацієнтів та користувачів m-Health i e-Health. Для подолання нерівності і набуття цифрової компетентності потрібно об’єднати зусилля навчальних закладів, громад та держави у створенні відповідних інституцій та фінансованих програм ліквідації цифрової некомпетентності викладачів, лікарів, вчителів і окремих груп населення старшого віку. Набуття цифрової компетентності викладачами та слухачами суттєво покращить якість і доступність освітніх послуг і результати управління якістю навчального процесу на основі міжнародних стандартів.
\end{abstract}

Ключові слова: цифрова компетентність викладача і слухача; цифрова нерівність; післядипломна професійна освіта; нові компетенції викладача.

The aim of the work - to identify the reasons for the inadequate teacher's digital competence and the digital divide between faculty, students and users of M-Health and E-health services as a problem of higher education institutions in transition to distance education and a wider inclusion to e-education space and modern digital medicine.

The main body. The essence and content of the new competences in digital technology for faculty and students are considered in The Digital Competency Framework 2018 together with associated tools in the updated version of key competences for life long specialist training, approved by the European Parliament and the European Council on January 17, 2018. The reasons of digital divide between faculty, students of postgraduate education courses and users of e-education and digital medicine are analyzed. Conclusions are made aiming at overcoming the digital divide between faculty, students and users of digital technologies.

Conclusions. Development of effective e-learning and e-health is impossible without overcoming the digital divide between listeners and teachers, doctors and patients, as well as m-Health and e-Health users. To overcome digital divide and gain competence, it is necessary to combine the efforts of educational institutions, communities and the state in order to create appropriate institutions and funded programs and eliminate the digital incompetence of faculty, doctors, teachers and certain older population groups. The acquisition of digital competence by faculty and students will significantly improve the quality and availability of educational services and results of quality management in the educational process based on international standards.

Key words: digital competence of faculty and students; digital divide; post-graduate professional education; new competences of a lecturer.

Вступ. Зі створенням в Україні електронного освітнього простору, розвитком і залученням основної частини спеціалістів до медійної сфери, створилась ситуація, коли ВНЗ можуть використовувати електронні засоби користувачів для дистанційного і безперервного навчання фахівців.

(C) Т. М. Клименко, Т. В. Сандуляк, О. А. Сердцева
Цифрова медицина (digital health) об’єднує цифрові технології для вирішення проблем пацієнтів і здорового населення, зокрема через m-Health - використання смартфонів в охороні здоров'я та е-Health-електронних систем, включаючи телемедицину та віддалений моніторинг на рівні лікувально-профілактичних закладів і органів управління громади і держави. 
3 розвитком персоналізованої медицини всюдисущі соціальні медіа заповнили мережу валом всякої інформації. Для вільного орієнтування в такому потоці інформації потрібні нові компетенції як слухачів, так і викладачів. I ті й інші, за концепцією Марка Пренски, розподілились на дві категорії: “Digital Immigrants” (“іммігранти”) - народилися до цифрової революції та “Digital Natives” (“аборигени”) - народилися після неї. Сьогодні серед слухачів післядипломної освіти 60 \% “аборигенів”, а серед викладачів близько 55 \% “іммігрантів”, що створює основну цифрову нерівність користувачів е-освіти. Незнання англійської мови, недостатність якісних відкритих для користування контентів, необхідність витрачати велику кількість часу для пошуку, фільтрації та аналізу інформації також підсилюють цифрову нерівність викладачів. Серед викладачів 95 \% елементарних користувачів ПК без знань основ програмування, а серед слухачів лише близько 30 \% володіють персональною інформаційною безпекою, етикою спілкування в мережі, знають основи програмування. Нерідко виникає питання - хто у кого і чого може навчитись дистанційно без відповідної цифрової компетентності?

Мета роботи - встановити причини недостатньої цифрової компетентності викладача та цифрової нерівності викладачів, слухачів і користувачів m-Health i e-Health послуг як проблеми переходу ВНЗ на дистанційну освіту та ширшого впровадження в електронну освіту і медицину сучасних цифрових технологій.

Основна частина. "Нам потрібно наново визначити та побудувати ясне розуміння того, для чого ми навчаємо, чому ми це робимо, і кому служить наша система освіти...” (Дж. Моравець, 2015) [1].

Європейським парламентом та Радою ЄС 17 січня 2018 року схвалені для користування в оновленій редакції ключові компетентності для навчання спеціалістів упродовж життя, серед яких появились нові та чітко визначені рамки цифрової компетентності, ї̈ значення в дипломній та післядипломній підготовці кваліфікованих кадрів. Чому цифрова компетентність викладачів не відповідає вимогам часу та як її покращити? Недостатня цифрова компетентність викладача - одна з проблем переходу ВНЗ на дистанційну освіту та ширшого впровадження в електронну освіту і медицину сучасних цифрових технологій. Компетентнісний підхід лежить в основі національних рамок кваліфікацій різних країн, зокрема й України. На засіданні КМ України від 28.03.2018 року затверджено Положення про систему безперервного професійного розви- тку фахівців у сфері охорони здоров'я. Безперервний професійний розвиток фахівців - це процес навчання та вдосконалення професійної компетентності фахівців після здобуття ними вищої освіти у сфері охорони здоров'я та післядипломної освіти в інтернатурі. Це дозволить фахівцю підтримувати або покращувати стандарти професійної діяльності відповідно до потреб сфери охорони здоров’я. Процес триває впродовж усього періоду професійної діяльності, і фахівець постійно вдосконалює свої знання, вміння і навички, як і вдосконалюються сам процес проведення безперервної підготовки і ті, хто його втілюють в життя, - викладачі факультетів дипломної та післядипломної підготовки.

Щодо підготовки в державі лікарів за останнє десятиліття зроблено багато, але всі вони, навіть після інтернатури, ще далекі від компетентного виконання поставлених перед ними завдань. Для подолання цієї невідповідності у березні 2018 року Урядом було прийнято Постанову “Про затвердження Порядку здійснення єдиного державного кваліфікаційного іспиту для здобувачів освітнього ступеня магістра за спеціальностями галузі знань “Охорона здоров’я”. МОЗ України впроваджує нові механізми атестації фахівців. Вперше за роки незалежності створено комплексний підхід до проведення єдиного державного кваліфікаційного іспиту для медичних спеціальностей. Атестація здобувачів ступеня вищої освіти “магістр” за спеціальностями галузі знань “Охорона здоров’я” включає такі компоненти: інтегрований тестовий іспит “КРОK”; структурований практичний (клінічний) іспит на володіння практичними навичками; міжнародний іспит з основ медицини та іспит з англійської мови професійного спрямування. На нашу думку, впору був би ще й іспит з володіння технологіями цифрової медицини, яка є невід’ємною частиною половини часу виробничої діяльності фахівців. Але такий іспит можна запровадити для ліцензування діяльності та атестації спеціалістів.

Отже, вже з цього року до факультетів післядипломної освіти прийдуть ще недосвідчені, але вже підготовлені на міжнародному рівні спеціалісти зі знаннями іноземної мови, користувачі цифрової техніки для подальшого професійного зростання. А з чим зустрінуть їх викладачі, які ще не набули цифрової компетентності? Цифрові нерівності викладачів, слухачів і користувачів m-Health i e-Health послуг гальмують впровадження електронної освіти та електронної охорони здоров’я в громаді і суспільстві. 
Цифрову нерівність (Digital divide) інтерпретують як: “розрив між окремими індивідами, підприємствами, географічними регіонами на різних соціально-економічних рівнях у доступі до інформаційних комп’ютерних технологій і їх використанні з метою доступу до Інтернету для широкого кола заходів” [2]. В Україні частка користувачів цифрових технологій у 2017 році становила 43,4 \% від усього населення, що на третину менше, ніж у країнах Європи. Серед користувачів і слухачів ВНЗ послуговуються m-Health та e-Health більше $70 \%$, а серед викладачів майже 80 \%, переважно особи до 40 років. Викладачів старшого віку менше, що зумовлено їх недостатньою цифровою компетентністю у сучасному розумінні значення цифрових технологій в електронній медицині, навчанні, викладанні, управлінні освітою.

Для того щоб викладачу пристосуватись до сучасного інформаційного суспільства, потрібно постійно змінюватись і заново вчитися. Як не парадоксально, але саме у дипломній та післядипломній підготовці фахівців найбільше проявляються демографічні, соціально-економічні і психологічні складові цифрової нерівності, особливо при відтворенні інтелектуальної еліти. В закладах освіти застаріле технічне обладнання, впродовж тривалого історичного періоду склалися групи впливу, суспільні домінанти. Досі поширені, традиційні за радянських часів, практики “беззаперечної підпорядкованості”, “заперечення особистої ідентичності”, “обмеження у часі і просторі”, навали паралельної паперової документації та ін. [3].

Необхідність переходу до інших, нових, освітніх практик викликана потребою подолання розриву між ВНЗ та новими освітніми інституційними утвореннями. Цю невідповідність фіксують роботодавці, пацієнти, батьки хворих дітей, адже домінуючі практики організаційного життя суттєво відрізняються від навчальних ситуацій, які засвоїли спеціалісти. Практик особистої унікальності, вміння самостійно мислити і приймати рішення, працювати в проектах і над проектами, мобільно орієнтуватись у нових ситуаціях, бути стійкими до стресів та реорганізацій в суспільстві на рівні особистість-колектив-громада-держава навчають далеко не всі викладачі.

Соціальні нерівності в освітніх практиках електронної цивілізації в суспільстві потребують вирішення. Серед причин опору інноваціям можна виділити неправильне розуміння викладачами цілей змін, яке виникає, бо деякі викладачі не спроможні оцінити наслідки здійснення стратегії змін і не бажають щось змінювати. Навіть досвідченим викладачам старшого віку притаманні перестороги, що вони не зможуть навчитися потрібних нових навичок або нової роботи та позбавляться свого статусу. Формування нових організаційних цінностей і норм електронної освіти вимагають нових принципів роботи викладача, а відповідно і додаткових часових, фізичних, матеріальних ресурсів, а головне - необхідність одночасно змінюватись всім суб'єктам освітнього процесу. Внаслідок такого тихого опору як викладачів, так і слухачів, затягується тривалість процесів реформ, а результативність освіти та якість підготовки випускників і підвищення кваліфікації спеціалістів 3 року в рік знижуються.

Для подолання цифрової нерівності потрібно викладачам, слухачам курсів (циклів) післядипломної підготовки і лікарям володіти оновленим у січні 2018 року переліком ключових компетентностей для навчання впродовж життя, схваленим Європарламентом і Радою ЄС. Серед них: 1. Грамотність (Literacy competence); 2. Мовна компетентність (Languages competence); 3. Математична компетентність та компетентність у науках, технологіях та інженерії (Mathematical competence and competence in science, technology and engineering); 4. Цифрова компетентність (Digital competence); 5. Особиста, соціальна та навчальна компетентність (Personal, social and learning competence); 6. Громадянська компетентність (Civic competence); 7. Підприємницька компетентність (Entrepreneurship competence); 8. Компетентність культурної обізнаності та самовираження (Cultural awareness and expression competence).

Які компетентності з перелічених відносяться до діяльності лікаря і мають бути задіяні викладачами при підготовці та проведенні занять у післядипломній освіті? Відповідь - всі! Викладач адаптує ключові компетенції до змісту кожної теми навчального плану і програми курсу (циклу) в процесі складання методичних розробок (сценаріїв) лекційних, семінарських і практичних занять, орієнтуючись на вік, стаж роботи і досвід слухачів, а також при написанні навчально-методичних посібників і методичних рекомендацій для самостійного вивчення матеріалу. Але в умовах сьогодення на основний план виходить цифрова компетентність як викладача, так i слухача та користувачів систем електронної освіти та охорони здоров'я.

Формування вузівської Е-платформи електронних курсів, створення електронних підручників, 
розроблення курсів дистанційного навчання за програмами післядипломної освіти та розроблення системи безперервного дистанційного навчання для підвищення кваліфікації на робочому місці неможливі без комп’ютерної грамотності та набуття викладачами цифрової компетентності. Всі необхідні сучасні компетенції викладача і слухача пов’язані між собою. Творчість та інноваційність $\epsilon$ невід'ємною часткою обізнаності та самовираження особи і виявляються у всіх ключових компетентностях.

У нових компетентностях значно більшого значення, ніж у попередніх від 2006 року, надається цифровій компетентності. Без цифрової компетентності сьогодні викладач і слухач не зможуть досягти очікуваної ефективності своєї діяльності, зокрема: розуміння суті завдань і вирішуваних проблем; набуття досвіду в своїй сфері; уміння обирати засоби й способи діяльності, адекватні конкретним обставинам місця й часу; почуття відповідальності за досягнуті результати; здатності учитися на помилках і вносити корективи в процес досягнення мети; стійкості до стресів і невдач та їх прогнозування і уникання в роботі та побуті.

Для набуття цифрової компетентності потрібно освоїти знання, вміння і отримати досвід пізнавальної діяльності у галузі інформатики й цифрових технологій; здійснення відомих способів інформаційної діяльності у своїй предметній сфері з використанням сучасних електронних систем освіти та медицини; володіти професійно зорієнтованими цифровими технологіями і досягати здійснення емоційно-ціннісних відносин, пов’язаних із використанням цифрових технологій освіти та медицини.

Цифрова компетентність - це здатність і зацікавленість спеціаліста працювати з інформацією, орієнтуватися в їі невичерпних потоках, уміння одержувати інформацію з різних джерел, користуватися різними їі носіями. В останні роки цифрова компетентність охоплює 21 навчальний результат у 5 сферах: 1) інформаційна грамотність, включаючи керування контентом; 2) спілкування та співпраця, участь у роботі колективу, громади і суспільства; 3) створення цифрового контенту, включаючи етичні принципи; 4) безпека та захист даних; 5) розв’язання проблем на високому та експертному рівні.

Для успішного формування цифрової компетентності слухачів і лікарів на курсах (циклах) післядипломної підготовки насамперед висока цифрова компетентність має бути у викладача. Без цифрової компетентності викладача, навіть за дуже високих його професійних і фахових знань і вмінь, неможливе формування національної Е-платформи дипломної та післядипломної освіти та електронної охорони здоров'я [4].

Складовими цифрової компетентності викладача $\epsilon$ технологічна, інформаційна та цифрова грамотність і медіа-грамотність. Суть цифрової компетентності викладача і слухача - здобувати інформацію з різних джерел у зрозумілому вигляді; працювати з різними відомостями в різних контентах; критично оцінювати відомості і обирати дані доказової медицини і належної клінічної практики; використовувати в професійній діяльності цифрові технології; мати відповідальне ставлення до цифрових технологій для соціальної взаємодії і етичну поведінку в медіа-просторі.

Висновки. Побудова ефективної електронної освіти та електронної охорони здоров'я неможлива без подолання цифрової нерівності слухачів і викладачів, лікарів і пацієнтів та користувачів m-Health i e-Health. Для подолання нерівності і набуття цифрової компетентності потрібно об’єднати зусилля навчальних закладів, громад та держави у створенні відповідних інституцій та фінансованих програм ліквідації цифрової некомпетентності викладачів, лікарів, вчителів і окремих груп населення старшого віку. Набуття цифрової компетентності викладачами та слухачами суттєво покращить якість і доступність освітніх послуг і результати управління якістю навчального процесу на основі міжнародних стандартів.

3. Чепак В. В. Соціальні нерівності в освітніх практиках електронної цивілізації. Освітні дисонанси: flexibility vs stability / В. В. Чепак // Нові нерівності - нові конфлікти: шляхи подолання : тези доповідей III Конгресу Соціологічної асоціації України [Електронний ресурс] / відповідальна за випуск проф. 
Л. Г. Сокурянська. - Режим доступу : www.sau.kiev.ua/ docs/20171205/tezi.pdf.

4. A Joint Project with the World Bank MOH Ukraine “Serving People, Improving Health” [title from screen] [e- source] - Accessible by the link: http://wb.moz.gov.ua/en/ struktura-proektu/komponent-2_-tsentralni-komponenty/eHealth.html.

\section{References}

1. Moravets, Dzh. (2015). Navchannia yake evoliutsionuie [Education that evolves]. - Retrieved from: https://www. manifesto15.org/ua/ [in Ukrainian].

2. Bauman, Z. Tekuchaya modernist: vzglyad iz 2011 goda: lektsiya [Liquid modern world: The view of 2011: Lecture]. Retrieved from: http://polit.ru/lectures/2011/05/06/bauman [in Russian].

3. Chepak, V.V. Sotsialni nerivnosti v osvitnikh praktykakh elektronnoi tsyvilizatsii. Osvitni dysonansy: flexibility vs stability [Social inequalities in the educational practices of electronic civilization. Educational dissonances:

flexibility vs stability]. Naukove vydannia: Novi nerivnosti novi konflikty: shliakhy podolannia. Tezy dopovidey III kongresu sotsiolohichnoi asotsiatsii Ukrainy - New inequalities - new conflicts: ways to overcome: abstracts of the III Congress of the Sociological Association of Ukraine. Retrieved from: www.sau.kiev.ua/docs/20171205/tezi.pdf [in Ukrainian].

4. A Joint Project with the World Bank MOH Ukraine "Serving People, Improving Health". - Retrieved from: http://wb.moz.gov.ua/en/struktura-proektu/komponent-2_tsentralni-komponenty/e-Health.html.

Отримано 20.04.18 